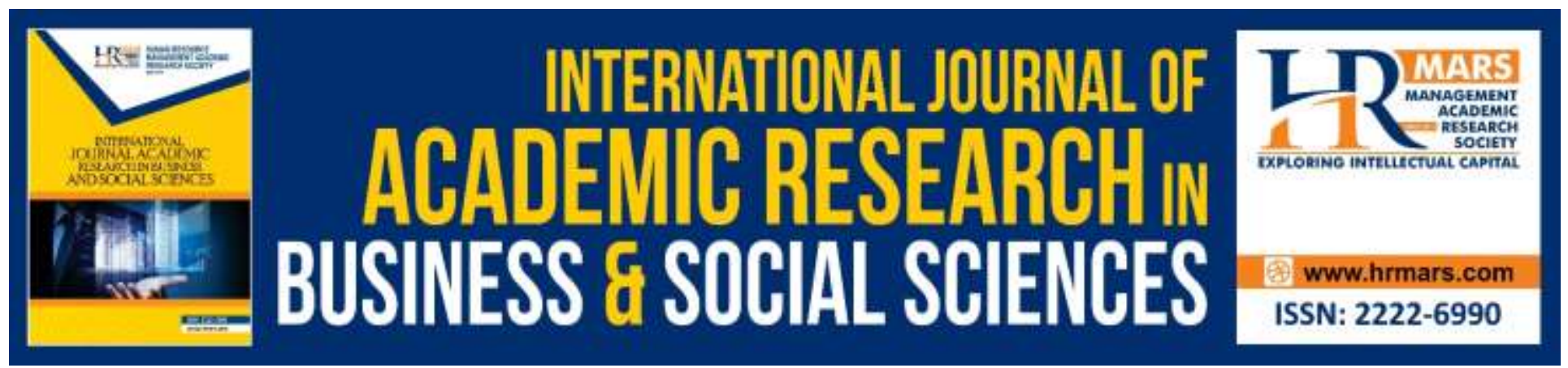

\title{
The Source of Knowledge of School Football Teachers Influencing Football Coaching Pedagogy: Needs Discovered
}

Najib Razak, Zulakbal Abd Karim, Ahmad Hashim

To Link this Article: http://dx.doi.org/10.6007/IJARBSS/v10-i6/7313

DOI:10.6007/IJARBSS/v10-i6/7313

Received: 02 April 2020, Revised: 06 May 2020, Accepted: 16 June 2020

Published Online: 26 June 2020

In-Text Citation: (Razak et al., 2020)

To Cite this Article: Razak, N., Karim, Z. A., \& Hashim, A. (2020). The Source of Knowledge of School Football Teachers Influencing Football Coaching Pedagogy: Needs Discovered. International Journal of Academic Research in Business and Social Sciences, 10(6), 430-439.

Copyright: (c) 2020 The Author(s)

Published by Human Resource Management Academic Research Society (www.hrmars.com)

This article is published under the Creative Commons Attribution (CC BY 4.0) license. Anyone may reproduce, distribute, translate and create derivative works of this article (for both commercial and non-commercial purposes), subject to full attribution to the original publication and authors. The full terms of this license may be seen at: http://creativecommons.org/licences/by/4.0/legalcode

Vol. 10, No. 6, 2020, Pg. 430 - 439

http://hrmars.com/index.php/pages/detail/IJARBSS

JOURNAL HOMEPAGE

Full Terms \& Conditions of access and use can be found at http://hrmars.com/index.php/pages/detail/publication-ethics 


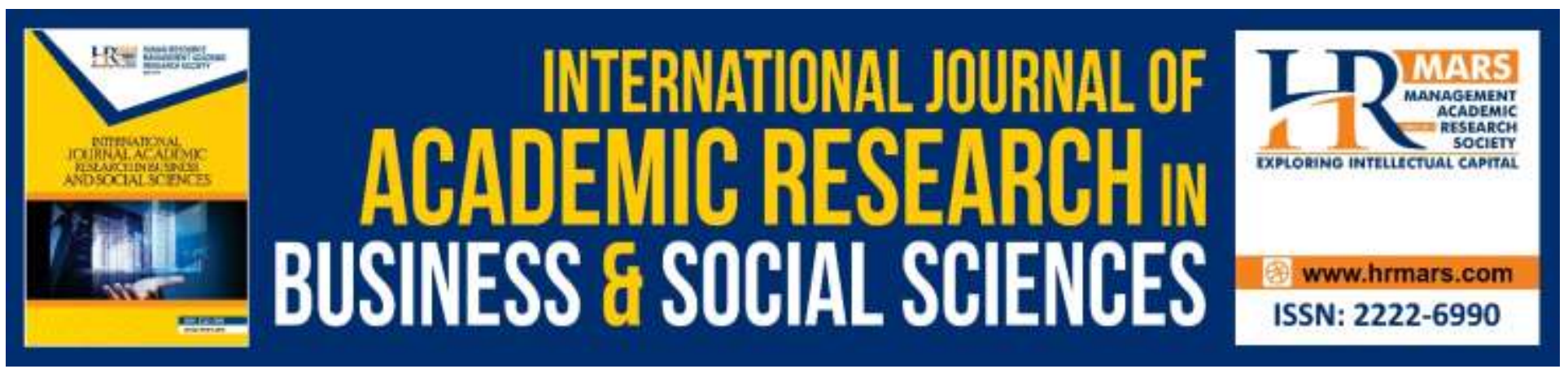

\title{
The Source of Knowledge of School Football Teachers Influencing Football Coaching Pedagogy: Needs Discovered
}

\author{
Najib Razak, Zulakbal Abd Karim, Ahmad Hashim \\ Sultan Idris Education University \\ Email: najibrazak30@yahoo.com, zulakbal@fsskj.upsi.edu.my, ahmad@fsskj.upsi.edu.my
}

\begin{abstract}
This study aims to identify the source of knowledge that influence school teachers football coaching pedagogy. Using a Grounded Theory (Corbin \& Strauss, 1990) approach, a qualitative study, an openended semi structured interview guide question developed. Purposive sampling technique was used in this study to recruited seven school football teachers. Results of the interview were transcribed verbatim and were analyzed using Atlas.ti software through open coding, axial coding and selective coding process. Based on the theme emerged from the data analysis, most of coaches involved in this study convey their thought that needs of football training module should have elements of (1) spesific age related objectives, (2) tactical aspects, (3) training periodization, (4) physical fitness components and (5) variety of football training drills. Training means to train what is purposely being trained. Therefore, to help teachers in conducting their football training better, the football governing body should adopt tested and proven football training module as a guidance that can enhance teachers coaching competency to coach their school football team in the future.
\end{abstract}

Keywords: Coaching, Football, Football Training Modules, Training Periodization

\section{Introduction}

In the last decade, due to its popularity, football has been extensively studied. Football is the most popular sport in Malaysia (Zulakbal \& Ali, 2017) and played at various levels. Since football has serious consequences, it is imperative to understand better what is the best football game pattern for Malaysian football. How Malaysia football curriculum can be standardized and applied across the country? A situation is a fundamental question that should be on the minds for those who involved in football at the national or grassroots level at school (Berger, 2017). It is essential to understand the impact of a school teacher who plays an important role in the development of football players at the grassroots level. They are many training methods practised, but some of them are on the opinions, personal knowledge and experience of the coach (Verheijen, 2014). However, is there any official guidance or reference that teachers or school coaches can use to train their school's football team in 
a tournament organized by the Malaysia Ministry of Education (Zulakbal, Najib, \& Ali, 2018)? In the modern football era, isolated training is no longer relevant (Zulakbal, Hanis, \& Ali, 2018). Footballers never run or jog constanty at the same speed in a game. They run for short distance, they change direction often and move backwards or forwards. Physical conditioning relevant to football can be achieved with the ball, it plays a crucial rule in causing all the movement in game situation. Players are more motivated during a training session when teachers perform small-sided games and no longer need to run 10-round laps to increase their cardiovascular endurance fitness levels (Borges et al., 2018; Özcan, Eniseler, \& Şahan, 2018).

According to Zulakbal \& Ali (2017), coaches in Malaysia face various challenges, including unclear coaching direction and a lack of formal guide curriculum for coaches. Bert Van Lingen, (2016) states that each age related category in football requires different approaches and training methods by coaches. Defining the targets that the team should achieve, explaining the short-term and longterm development plans, and selecting appropriate football training drills according to these different age related categories is important for teachers or coaches (Berger, 2017; Lingen, 2016; Verheijen, 2014; Kolfschooten \& Verheijen, 2015).

\section{School Teacher Issues in Football Training}

According to Zulakbal, Najib, \& Ali, (2018), teachers or coaches need to have their coaching sources of knowledge which can help them to improve their coaching skills. Coaching a football team without training modules or detailed educational resources as a guide will waste time on the teacher and players and the objectives of the specific age related objective in football will not be achieved. Also, the player will not perform well during matches and training and cannot contribute to the development of the football team (Lingen, 2016).

There has been a heated debate in football for many years between school teachers who think that technique training should take place in football training and coaches who believe in isolated technique training. The main reason why this discussion is already going on for many years is the fact that it takes place at a subjective wavelength. In other words, it's opinions against opinions and experience versus experience. The only way to solve this subjective status quo is by zooming-out and introducing objective references based on the characteristics of the game.

The problem of coaching in football is now a new one. Based on the purpose analysis of the game, it shows that football technique is the execution of a decision that can only be trained in football situations in which players have to make a decision. In an isolated training situation without opponents a player does not have to make a decision. In that case, the player is not practicing the execution of a decision but just the execution of a technique. In other words, he is not developing football technique. Despite the philosophical analysis of the game, all around the world there are football coaches or school teachers who stick to isolated technique training based on their subjective opinion. They believe that players have to start with isolated technique training before they can do more complex football training.

Researchers have identified numerous expertise, comprehensive and holistic (physical, technical, tactical, and psychological) approaches that may contribute to grassroots football development in this respect. The idea behind the study is quite simple. A specific football training 
INTERNATIONAL JOURNAL OF ACADEMIC RESEARCH IN BUSINESS AND SOCIAL SCIENCES

Vol. 10, No. 6, June, 2020, E-ISSN: 2222-6990 @ 2020 HRMARS

module should be made that emphasizes on the specific tactical understanding of a particular age related category objective in football as an official source of knowledge for school teachers to train their school's football team for the championship.

\section{Research Objective}

The objectives of this study are to

1. Identify the source of knowledge school football teachers needs to implement the training pedagogy of their school football team.

2. Identify what pedagogic approach teachers use to coach their school football team.

3. Identify what improvements can teachers make in achieving their objective while carrying out the pedagogy of the school football training.

\section{Research Question}

1. What is the source of knowledge school football teachers need to implement the training pedagogy of their school football team?

2. What are the pedagogic approach teachers use to coach their school football team?

3. What improvements can teachers make in achieving their objective while carrying out the pedagogy of the school football training?

\section{Methodology}

This study is a qualitative study with the Grounded Theory method (Corbin \& Strauss, 1990) in which this study captures a specific phenomenon for a particular individual or group of individuals (Ghazali and Sufean, 2016). The selection of the Grounded Theory method is considered appropriate because the researcher has in-depth knowledge of research experience in the field of football coaching. With such knowledge and experience, researchers can interpret data from a phenomenon or event that is observed and understood during data collection (Ghazali and Sufean, 2016). The ability of researchers to interpret data is strongly influenced by the depth of the theoretical knowledge, experience and research from the studied field and the amount reading literature review. These factors allow researchers to obtain rich and sensitive information about the phenomenon under study (Hussin, 2014; Corbin \& Strauss, 1990).

\section{Sampling}

Purposive sampling was used in this study to identify the teacher sources of knowledge to coach their school football team. Through this purposeful sampling method, participants who are selected by the researcher have information that the researcher wants to know about the current situation of an issue in a well-researched location (Cresswell, 2008). It is important to make sure the most relevant individuals included in this study are responsible for coaching their school football team. Therefore, to take part in this study, seven school teachers have been chosen. According to Spencer and Spencer (1993), to obtain valuable qualitative data, seven participants were sufficient, while Ghazali and Sufean (2016) stated that the small sample size (1-5) was sufficient as long as participants met all the sampling criteria. 
INTERNATIONAL JOURNAL OF ACADEMIC RESEARCH IN BUSINESS AND SOCIAL SCIENCES

Vol. 10, No. 6, June, 2020, E-ISSN: 2222-6990 @ 2020 HRMARS

\section{Instrument}

The researcher conducted in-depth interviews using a semi-structured open-ended questionnaire to identify the sources of knowledge, approaches and issues encountered by teachers who coach their school's football team in this study. As a consequence of the literature review, and through the validation process, the researcher developed the interview guide to make sure the questionnaire use in the interview are focus on the objective of the study. According to Hashim (2015), validity is a measure of what should be measured. The interviews mainly contained open-ended questions and were held on a one-to-one basis allowing the participants to address the issues. An open-ended question allows the same interview questions to two or more different participants for the same or similar consistency answers to be obtained. The Semi-structured interview also allows the questions to be pre-determined by the researcher. In contrast, the answers from questions are open to additional question and can be developed according to the needs of the researcher and participants. At the end of the interview, the researcher thanked participants for taking part in the study.

\section{Data Analysis}

The data is obtained through the use of interviews. The results of the interview transcripts were analyzed by using Atlas. It software through open coding, axial coding and selective coding. Coding is a process of data analysis, in which data from interview results are detailed and conceptualized together in new ways. Coding is the process by which new theory is formed from the results of interviews (Corbin \& Strauss, 1990). This approach allows a more detailed analysis of some aspects of the data.

\section{Findings}

This section summarizes and discusses the main findings of the study. This study aims to identify the sources of knowledge, approaches, issues and challenges that school football teachers face in implementing their school football team's training pedagogy. Here are the profiles of the participants involved in this study:

Participant profiles

\begin{tabular}{|c|c|c|c|c|c|c|c|}
\hline $\begin{array}{c}\text { Participant } \\
\text { Profile }\end{array}$ & $\begin{array}{c}\text { Participa } \\
\text { nt A }\end{array}$ & $\begin{array}{c}\text { Participa } \\
\text { nt B }\end{array}$ & $\begin{array}{l}\text { Participa } \\
\text { nt C }\end{array}$ & $\begin{array}{c}\text { Participa } \\
\text { nt D }\end{array}$ & $\begin{array}{l}\text { Participa } \\
\text { nt E }\end{array}$ & $\begin{array}{l}\text { Participa } \\
\text { nt F }\end{array}$ & $\begin{array}{c}\text { Participa } \\
\text { nt G }\end{array}$ \\
\hline Education & Degree & Degree & Degree & Degree & Degree & Degree & Degree \\
\hline $\begin{array}{l}\text { Coaching } \\
\text { Licence }\end{array}$ & $\begin{array}{c}\text { No } \\
\text { Licence }\end{array}$ & C Licence & D Licence & D Licence & D Licence & D Licence & B Licence \\
\hline $\begin{array}{l}\text { Highest } \\
\text { Level in } \\
\text { Coaching }\end{array}$ & School & School & School & School & State & School & State \\
\hline $\begin{array}{l}\text { Highest } \\
\text { Level as } \\
\text { Player }\end{array}$ & School & $\begin{array}{c}\text { Universit } \\
\mathrm{y}\end{array}$ & $\begin{array}{c}\text { Universit } \\
\mathrm{y}\end{array}$ & $\begin{array}{c}\text { Universit } \\
\mathrm{y}\end{array}$ & $\begin{array}{c}\text { Universit } \\
\mathrm{y}\end{array}$ & $\begin{array}{c}\text { Universit } \\
\mathrm{y}\end{array}$ & $\begin{array}{c}\text { Universit } \\
\mathrm{y}\end{array}$ \\
\hline $\begin{array}{c}\text { Experience } \\
\text { as School } \\
\text { Teachers }\end{array}$ & 15 years & $\begin{array}{l}\text { Eight } \\
\text { years }\end{array}$ & $\begin{array}{l}\text { Three } \\
\text { years }\end{array}$ & $\begin{array}{l}\text { Two } \\
\text { years }\end{array}$ & $\begin{array}{c}\text { Two } \\
\text { years }\end{array}$ & $\begin{array}{l}\text { Two } \\
\text { years }\end{array}$ & 16 years \\
\hline
\end{tabular}


INTERNATIONAL JOURNAL OF ACADEMIC RESEARCH IN BUSINESS AND SOCIAL SCIENCES

Vol. 10, No. 6, June, 2020, E-ISSN: 2222-6990 @ 2020 HRMARS

Several new themes were identified during the interview. Our most intriguing finding is that teachers have no official source of knowledge, training pedagogical elements and suggestions from teachers are issues that need attention in this study.

No Official Sources of Knowledge

The majority of the study participants stated that there were no official sources of knowledge and guidance provided by the football governing body that could help them to train the school's football team for the tournament. For example, participant A states that:

Since I am a school football coach, there was no official reference source I could refer to. The 1 Murid 1 Sukan module is available on the internet, but the module is for students to engage in sports activities during school curriculum and not for the tournament. There is no official resources or module for the tournament.

Participant B stated that

Training modules are available on the internet but not for local content. How about our local school coaching content? Besides that, the National Football Development Program (NFDP) module is available but not for tournament content. That is only basic information about NFDP itself.

Participant C stated that

We want to have a real football training module. Currently, our coaching session is based on our own experience, doing some trial and error coaching session and watching videos from YouTube and Facebook.

Participant D stated that

At the school level, there is no football-specific sources or reference is provided for teachers. We coach using our experience and little knowledge.

Participant F stated that

Please organize seminar or workshops, especially for teachers on how to coach the football team.

The element of training pedagogy

Participants are still confused about the approach they can use to coach their school's football team. Most participants who coach the school's football team do not know how to start their football training and what elements they need to train. For example, participant $D$ states that:

When I want to start my coaching session, I am not sure which element I should do first? Tactical or technical. I am not sure.

Participant C stated that:

Usually, I will start with fitness first because I have a degree in Sports Science. But when it comes to the tactical part, I leave it to the players to decide. 
INTERNATIONAL JOURNAL OF ACADEMIC RESEARCH IN BUSINESS AND SOCIAL SCIENCES

Vol. 10, No. 6, June, 2020, E-ISSN: 2222-6990 @ 2020 HRMARS

\section{Participant E stated that}

I have my training program, but I am not sure if my training program is right or wrong.

Participant A stated that

I do some training session, but when I ask opinion from senior coaches, they say that my training session is not suitable for my age category. He told me to do a more challenging session related with the age categories I was training for.

Participant B stated that

I want to do a training session, but I do not know how to do it. If I want to do a training session like attacking from the wing, I will refer to YouTube, and then if I want to coach defending part, I need to find another drill video from YouTube.

\section{Suggestion from Teachers}

The majority of participants felt that the best solution to solve the sources of knowledge should be provided to them so they would have guidance that focused on how to help them to coach the school's football team. For example, participant A states that:

Participant A stated that

Existing sources of knowledge among teachers are vital. I become a football coach because of my passion, and I'm not forced by anyone to do it. It may be possible for the football governing body involved to conduct a coaching course session according to the criteria of the football team and football tournament.

Participant B stated that

I expect that there are many courses that the football governing body should organize to guide teachers to become more effective in coaching football according to the trend of football. My suggestion is that there should be a detailed and comprehensive source of knowledge for the grassroots level in national football development.

Participant C stated that

The football governing body needs to provide a specific module related to age category football so that it is easier for teachers to do a coaching session.

Participant D stated that

It is also important for the Ministry of Education and football governing body to conduct seminars and courses with the teachers to improve the expertise of the teaching sector further as well as to develop skilled players.

Participant E stated that

It is producing a football training module or book that can guide teachers on how to train and develop the football team according to a specific age related category in football. Designing this football training module or book should be from the elementary level to middle school level category in football. 


\section{Discussion}

The interviews transcript is a vital contribution to this approach. A vital strength of the research lies within the fact that the participants needed a football training module according to age category in football as they had been training their football team without formal training modules provided by football governing body before. Also, the elements needed in the training module should be included and emphasized so that the teacher truly understands what needs to be trained. The findings are where the strength of our approach lies. A question like what kind of training drill is appropriate to guide them? What should coaching points be in each of the exercises in the football training module? What is the shape of the diagram in the module? Some of the teacher-coach their school's football team with a background in Sports Science or Physical Education knowledge. Their existing knowledge of training the physical aspects of the physical fitness component is tremendous. Still, the training program is isolated, general and non-specific in the football context and not specific to age category in football. They need to adjust their existing knowledge to adapt to the characteristic of football games when planning their team training sessions. Bert Van Lingen (2016) stated that coaching a football team without modules wasted teacher and student time and the objectives of the spesific age related category were not met.

According to Osman (2017), the Teaching Game for Understanding (TGfU), pedagogy is an appropriate approach to use by teachers to enhance the skills and techniques of a sport into real game situations. Throughout this respect, teachers engaged throughout coaching the football team of their school may use this approach as a tool, methodology or pedagogy for coaching their school football team. Through this approach, elements such as game tactical and physical fitness components are directly involved and can be performed with a lot of variety.

To the best of our knowledge, our work is the first to introduce such a solution for development football training modules for school teacher and coaches in Malaysia. In this regard, teachers should be provided with the best solution to solve the problem such as football specific training modules, coaching courses, knowledge sharing from individuals directly involved in coaching, mentor-mentee programs between experience coach that can guide teachers to coach their school's football team.

\section{Conclusion}

In conclusion, this study demonstrated that teachers have no official source of knowledge, need training pedagogical elements guidance and the suggestion from the teachers that need guidance such as spesific football training module to focuced on how to help them to coach the school's football team. Training means to train what is purposely being trained. The specific football training module of age related category in football should be provided by the football governing body to help school teachers in training their respective football teams. The elements such as specific age related objective for all age category in football, tactical aspects, training periodization, physical fitness component and variety of football training drills should be in the football training module as the best solution to solve problem for sources of knowledge to help the teacher. Players would still benefit, so they will experience through a proper football training session and achieve adequate development process. 


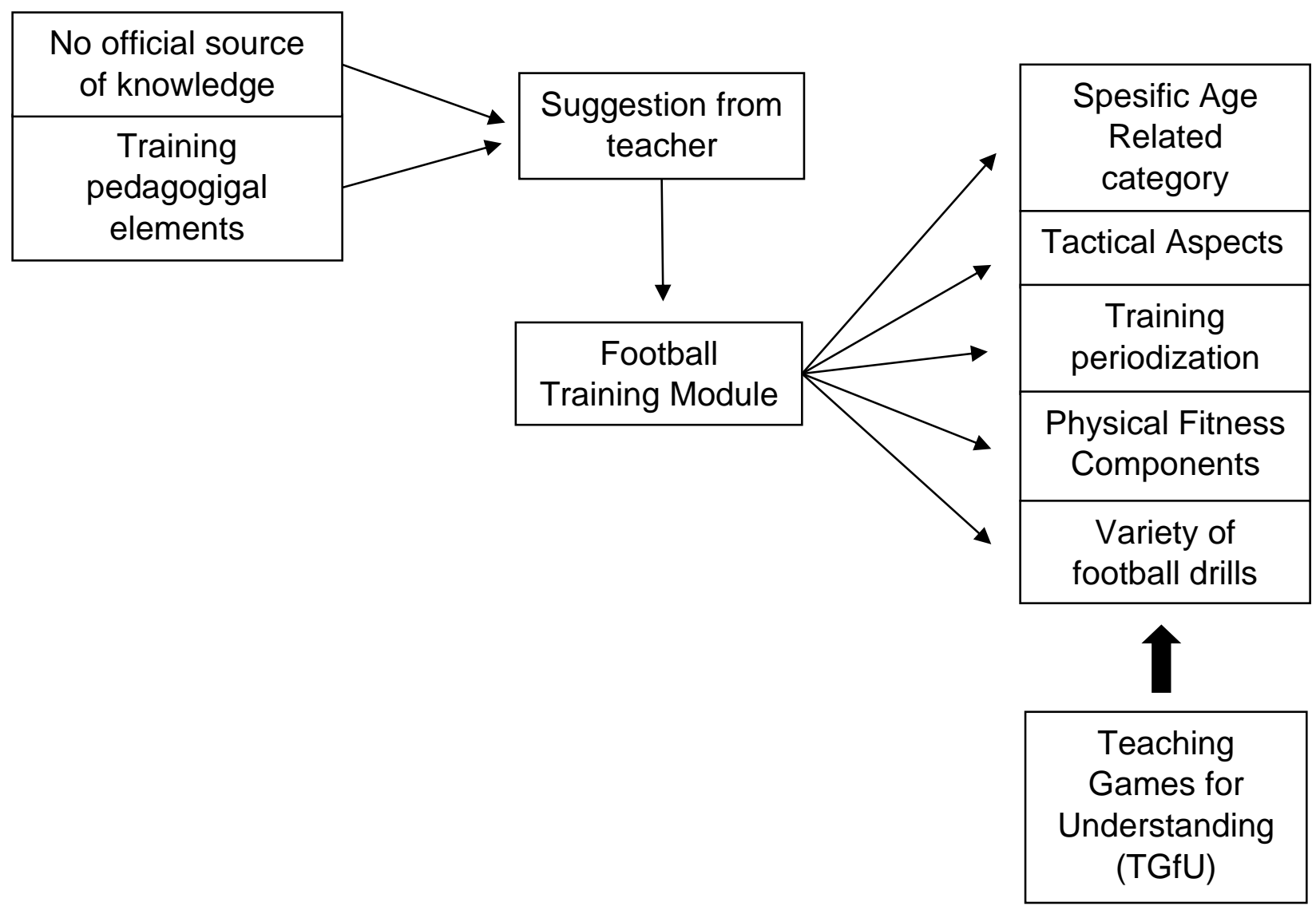

Figure 1: Sources of knowledge, approaches, issues and challenges that school football teachers face in implementing their school football team's training

\section{Acknowledgement}

The authors express gratitude to all teachers involved in this study.

\section{Conflict of Interest}

The authors declare no conflict of interest.

\section{Corresponding Authors}

Najib Razak,

Faculty of Sport Science and Coaching,

Sultan Idris Education University, 35900 Tanjong Malim, Perak, Malaysia

Email:najibrazak30@yahoo.com

\section{References}

Razak, N., Karim, Z. A., \& Hashim, A. (2020). The Source of Knowledge of School Football Teachers Influencing Football Coaching Pedagogy: Needs Discovered. International Journal of Academic 
INTERNATIONAL JOURNAL OF ACADEMIC RESEARCH IN BUSINESS AND SOCIAL SCIENCES

Vol. 10, No. 6, June, 2020, E-ISSN: 2222-6990 @ 2020 HRMARS

Research in Business and Social Sciences, 10(6), 391-400.

Ghazali, D., \& Sufean, H. (2016). Metodologi Penyelidikan dalam Pendidikan. Kuala Lumpur: Penerbit Universiti Malaya.

Kolfschooten, F. Van., \& Verheijen, R. (2015). How Simple Can It Be? The Netherland: World Football Academy BV.

Osman, A. (2017). Effects of Teaching Games for Understanding on Tactical Awareness and Decision Making in Soccer for College Students. Science, Movement and Health, 17(2), 170-176.

Retrieved from http://www.analefefs.ro/anale-fefs/2017/i2s/pe-autori/ASHRAF Osman 1.pdf

Özcan, I., Eniseler, N., \& Şahan, Ç. (2018). Effects of small-sided games and conventional aerobic interval training on various physiological characteristics and defensive and offensive skills used in soccer. Kinesiology: International Journal of Fundamental and Applied Kinesiology, 50(1), 56. https://doi.org/10.26582/k.50.1.12

Spencer L., \& Spencer S. (1993). Competence at Work: Model for Superior Performance. John Wiley \& Sons, New York.

Verheijen, R. (2014). The original guide to football periodisation: Always play with your strongest team (Part 1). Amsterdam: World Football Academy BV.

Hussin, Z. (2014). Aplikasi Pendekatan Grounded Thoery dan Pengekodan (Coding) dalam Analisis dan Interpretasi Data Kualitatif. Social Sciences Postgraduate International Seminar (SSPIS).

Zulakbal, K., \& Ali, N. (2017). Malaysia football coaches: Development characteristics. International Journal of Academic Research in Business and Social Sciences, 7(9), 305-312. https://doi.org/10.6007/IJARBSS/v7-i9/3326

Zulakbal, K., Hanis, A. G. A., \& Ali, N. (2018). Exploring Effective Training Methods to Improve Football Performance: Effects of Small Sided Games on Cardiovascular Endurance. International Journal of Engineering \& Technology, 7(2), 158-160.

Zulakbal, K., Najib, R., \& Ali, N. (2018). Designing model of career path development for National Football Development Program (NFDP): Directions, issues, challenges and sources of Kkowledge that influence and develop coaching expertise level. International Journal of Academic Research in Business and Social Sciences, 8(3), 542-550. https://doi.org/10.1109/IGARSS.2003.1294134 